\title{
Trickle-Down Economics' Arthur Lewis Fails: An Economic Development Study of Mount Bromo in Ngadisari Village, Sukapura District, Probolinggo Regency, East Java
}

\author{
Renny Candradewi Puspitarini ${ }^{*}$, Isrofiatul Anggraini \\ Department of Public Administration, Faculty of Social and Political Science, Panca Marga University, Probolinggo, \\ Indonesia
}

Abstract

In this paper, we will examine if the trickle-down effect has ever taken in rural Indonesia. One of the cases draws attention in economic development study is poverty and income gap from wealthiest people to the less fortunate larger group of people. The argument goes as trickle-down effect appears to be the best solution to eradicate poverty as well as to solve the income gap. Tourism has become a strategy targeted by the government to spread the trickle-down effect to the less fortunate larger group of people. The government believes by sustaining the growth in tourism would accelerate the trickle-down effect and brings a less fortunate group of people to better living. In its fundamental theory, the trickle-down effect has offered delusion where jobs would be created as the conditions are met. However, this paper argues that even in tourism the trickle-down effect strategy has served less for what it has promised. Through qualitative research in Ngadisari Village, a remote area, where Mount Bromo has been a tourism landmark globally, this paper finds that trickle-down effect has come with little benefit to uplift the living standard of the poor. Thus, the trickle-down effect has served only as delusions of growth government has ever aspired.

Keywords: humanism, Mount Bromo, tourism economics, tourist destination, trickle-down economics.

\section{INTRODUCTION}

The two-sector growth theory is often seen as a goal that inspires many development targets and economic growth. In the two-sector growth theory proposed by Arthur Lewis, growth may occur if it can take advantage of the abundant employment opportunities in the agricultural sector to encourage manufacturing and industrial growth in urban areas. This is what is prescribed as a precise recipe for boosting economic growth in developing countries throughout the 1980s [13].

This theory could gain popularity because it had become an icon of economic policy in Ronald Reagan's administration [4]. Therefore, such a familiar economic policy is called Reaganomics. The economic strategy that became the essence of Reagan economic policy that is supply-side economics or often known as trickle-down economics. Trickle-down economics is a term for economic policy that encourages growth in government spending, federal income tax cuts, and capital income taxes, reduces unnecessary government regulation and tightens money supply to curb inflation [3]. This was promoted by the government. The government believes the market has the best capability of realizing

Correspondence address:

Renny Candradewi Puspitarini

Email : renny.candradewi@upm.ac.id

Address : Dept. Public Administration, Panca Marga University, Probolinggo economic growth and development, better than them. Government intervention is considered to impede balanced economic growth.

Arthur Lewis's two-sector growth theory presents a growth process that runs vertically. For example, in the context of tourist destinations, many investors are interested to develop a particular tourist destination. This investor was supported by the low levy of capital income tax, laid-back regulation that exist and build various places of entertainment, place to stay, a place to eat, and others as a package of capital invested around tourist destinations $[5,6]$.

Places of entertainment, restaurant, homestay and hotel and others that opened will create employment opportunities for the community around. The community then took advantage of the tourist destinations. The community can benefit by doing economic activities such as cheap labor, hotel employees, employees at entertainment venues, and others. This potential opens opportunities for residents to earn income [7-9]. In the end, the purpose of developing tourist destinations both as a leading destination in the region and nationally is an effort to reduce poverty.

Through Home Visits construction of trickledown economics is not without its flaws [10-13]. The drawback lies in the opportunity for investors to invest in technologies that precisely suppress the absorption of labor-intensive 
workforce and the opportunity for investors to invest out to trigger capital flight $[14,15]$. This is also the main criticism of the theory of the development of two sectors at the same time doubt the effectiveness of trickle-down economics development [15]. Based on recent news, the Indonesian government has its strategic plan to develop tourism. Business tourism become the objective to seek what it calls New Bali. This plan also include developing a chain of Bromo Mountain-Tengger-Semeru Region as one of its roadmap [16]. Therefore, the author wishes to examine the extent to which this theory is applicable to be used in a developing country's economic approach, such as Indonesia. The author wants to know the extent to which trickle-down economics theory is applied to build a local economy in Mount Bromo.

The proposition of trickle-down economics emerged first in the post-World War II era, which often used as a claim to success western economic growth of its time $[1,4,10,11]$. Cutler and Katz [14] express Trickle-down economics was Okun first upgrading process in 1973. Anticipating many recent developments in the imperfect labor market theory, Okun believes that general growth can reach a hierarchy of skills, attract as many unemployed as possible and increase employment dealing with those trapped in cheap labor. At least until 1983, Cutler and Katz [14] thought Okun's argument was acceptable [12].

In summary, trickle-down economics drawn from traditional relationships between growth and poverty, which is why trickle-down economics able to run. This rate of growth raised through public intervention, in which policy also provides the means to overcome poverty and low income. Strategy trickle-down economics usually rely on political fetishism. While focused on raising overall average earnings, growth policies promise additional assistance to help those at the bottom of the growth pyramid.

Trickle-down economics implies that growth by itself will overcome the existing poverty with the assumption that growth will invite labor surplus [17]. Arestis questioned if growth could create excess employment, so based on Lewis's two-sector growth theory would automatically also create labor demand. Research conducted by Arestis on inland villages in India resulted in different conclusions. Arestis believes that economic growth followed by employment growth will make Trickle-down economics walk.
The fact that growth not always followed by job creation. Thus Trickle-down economics cannot run if growth goes on its own while not accompanied by the creation of labor.

Trickle-down economics theory is developed first by Arthur Lewis (1954) and expanded by Ranis and Fei (1968). The theory became one of the important topics in the literature on economic development in developing countries (Least Develop Countries/LDCs) in the 1950s and 1960s. This trickle-down theory became popular in America in Reagan's ex-President, but this approach has long since appeared in the United States. The application of this theory in the form of supply-side economics by President Reagan known as Reaganomics quite successfully suppress inflation and economic congestion in the United States. Among other things, there are two reasons for the success of Reaganomics. Trickle-down economics has the roots of the idea of classical liberalism revived by supporters of Ronald Reagan and Margaret Thatcher so often also called the school of neoliberalism. So that trickle-down economics is closely related to the economic ideology of neoliberalism [18].

Trickle-down economics theory explains that the progress of a group of people will themselves trickle down to create jobs and economic opportunities, which in turn will cultivate conditions for the uniform distribution of economic growth outcomes. The theory implies that economic growth followed by the vertical flow from the rich to the impoverished inhabitants themselves. The benefits of economic growth will be felt by the rich people first, and then in the next stage, the poor will begin to benefit when the rich start spending on the economic growth it has received.

This research is considerably less if not comparing with the previous research as comparison material. The comparison of the first study was Kurniawan [19] and the second was Santoso [20]. Kurniawan [19] and Santoso [20] explain specifically on the impacts of the tourism objects development in Umbul Sidomukti and Songa Rafting. Meanwhile, it is explained the economic impacts of tourism development. However, it lacks of explaining how economic growth theory is useful for providing comprehensive answers [21].

The objective of the research was to examine trickle-down economics capability to answer the problems in developing country, thus they can build its lagging region. The author wants to know the extent of trickle-down economics 
theory can promise local economic development. The research approach of Arthur Lewis' Trickledown economics on tourism was conducted for the economic development studies on the Mount Bromo tourism destination in Ngadisari Village, Sukapura District, Probolinggo Regency, East Java Year 2017-2018 need to be done given the lack of research around the same topic.

\section{MATERIAL AND METHOD}

This research is basic research that departs from a sense of interest in the theoretical gap between the two sectors theory which contains downward trickle-down economic growth. Location of the study where data were collected located in Ngadisari Village where Mount Bromo became a favorite tourist destination [22]. This research intends to recognize and obtain information on the characteristics possessed by Mount Bromo in explaining if there is a trickle-down economics process.

\section{Data Collection}

This research involves the process of collecting data that is analyzed qualitatively in which researchers can be involved in the test, reflect on the perception to achieve an understanding of human activities and social activities [23]. The researchers visit the location and made direct observations on the Ngadisari Village. Researchers conducted in-depth interviews to 20 respondents who can answer the research questions. These answers and observations company researchers to get the picture and formulate the conclusion. Snowball sampling is applied to collect approximately 100 people which encompasses workers in culinary and lodging sectors mini-stall owners.

\section{RESULT AND DISCUSSION Tourism in Indonesia}

Globalization in the field of technology and information has now allowed people to have the desire to travel across many interesting places [24]. Supported by more diverse and accommodative modes of transportation, people travel more easily in less time than they used to.

Traveling is one form of movement of people from one place to another temporarily [24]. Often, we find more and more people upload photos when visiting a particular tourist destination. It is transmitted to others around it to do the same thing that we are familiar with traveling. Not only the traveling to domestic tourist destinations, have even more people traveled out of the country. The fact that Indonesians love to go for travel is no longer a public secret. Indonesian people recorded to spend IDR 33 billion. It proved by the slump in the amount of revenue from online travel booking segment throughout 2017. From the data reported by Statista, the total revenue from the segment online travel booking in Indonesia until September 2017, reaching USD 2,417 million or almost IDR 33 billion [25].

According to Sharpley and Telfer [7], tourism is an effective tool that spurs income generation, employment, and creating a prospering community. Local governments who aware the tourism potential in their region can design development plans in the regions. Development in the area will trigger connectivity to the area [26-28]. Easy road access, adequate road guidance, adequate street lighting, which supported by the level of security will increase the tourist convenience during their visit. This needs strategic planning and policy maturity so that it can be realized [7].

In the current era of globalization, the tourism sector is the largest and strongest industry in financing the global economy. The tourism sector will be the main driver of the world economy in the 21st century and become one of the global industries [29-33]. Tourism has provided considerable foreign exchange for many countries [34]. Indonesia as the world's largest archipelago country consisting of 17,508 islands or also known as the archipelago or maritime country, has realized the importance of the tourism sector to the Indonesian economy as the growth of Indonesian tourism is always above the economic growth of Indonesia.

The tourist's expenditures can boost the income of the local population. The tourism industry is directed towards prioritizing large value-added, sustainable and inclusive tourism. Shopping for business travelers is always bigger than tourists in general. So, the tourism business is chosen as one of the important strategies [16]. Indicators of improving the quality of life seen on the level of connectivity both transport and data connections, the level of public participation in trade souvenirs typical area, as well as the level of communication between the community and tourists.

Visits of both foreign and domestic tourists are an economic blessing for people living around the tourist area. With the presence of adequate road connectivity and security and comfort, local people can quickly utilize it by building stalls. 
These stalls provide the needs that tourists can easily get at a reasonable price. The development and advancement of remote areas can encourage the rising standard of living and the economic level of the tourist destination. Hopefully, if tourism in the region is encouraged to go forward so that many tourists visit, the local economy will improve and the local area will grow to offset other famous tourist destinations such as Bali, Manado, Nusa Dua, and others [35].

\section{Issue of Tourism Development}

Unfortunately, the local government cannot turn a blind eye to the latent issue surrounding the development of tourist destinations and the surrounding areas. First, the level of the highest competitiveness of Indonesia's tourism industry which is still being dominated by big cities.

The city of Denpasar is ranked highest in the Indonesian Tourism Index. From the range of the index scale of 0 to 5 , the city got a score of 3.81. Environmental aspects of business support, governance, and infrastructure are the main proponents of excellence. Batam City was ranked next with a score of 3.73. Many tourist destinations are not less interesting, although the location is far from the residential population. Around 285 (57\%) districts/cities are below the national average score [32]. As a result, the number of foreign and local tourists visiting Mount Bromo is still far from significant.

Secondly, there is a classic problem spanning tourist experiences during their visit. Namely, the needs around or near tourist destinations are always sold at an unusual higher price. If this requirement is sold at a price above the market price, then it is impossible for tourists to return to buy products sold. As a result, the food and beverage sales sector and other mild needs will be sluggish.

Third, investments invested in Ngadisari and surrounding areas, based on findings, came from residents who live in cities and cities such as Surabaya and Jakarta. The hotels and inns built around Ngadisari Village are partly owned by residents of Surabaya, Jakarta and Malang. Generally, this owner is a class of people who are already in the middle or upper society. Ngadisari villagers are generally the bottom of their society take advantage of economic opportunities by opening food stalls, drinks, and cigarettes. Unfortunately, the stall that opened this was most of the buyers are citizens who happen to drop in from daily activities. Thus it can be concluded that the type of economic society in
Ngadisari Village is a subsistence traditional economic society.

Fourth, the tourist destination of Mount Bromo has not become a favorite tourist destination for tourists because of the connectivity is still far from significant. The charm of Mount Bromo is still inferior to the charm of the beach and culture in the city of Denpasar and surrounding areas. Undeniably, the road that leads closer to Mount Bromo can only be traversed by a single car line. As a result, if there happens to be a car that passes, then one of the cars must give in and ready to touch the rocks. The problem is when certain occasions were hels. For example, when Jazz Mountain was held the path density and congestion happens along this path.

Fifth, the connectivity that did not develop at all or very little progress made potentially perpetuating oligopoly power over tourist destinations. Almost ten years of public transportation paths to Mount Bromo as if not getting the attention of the local government even have the impression of omission. For almost ten years there is no widening of roads and minimal presence of security forces around this path. At night, this path included on the path of crime-prone. No wonder the emergence of the assumption that the deterioration of connectivity deliberately utilized to perpetuate the business rental car of hardtop. Streets that are rocky, less secure, prone to crime, and other security-prone areas cause only certain people who already know the terrain that can pass through without problems.

Supported by vehicle specifications, then the hardtop vehicle made the best choice to go through the gut test field. This is what makes foreign and local tourists directed to rent a hardtop rather than driving alone in the tourist area of Mount Bromo. This is the obstacle why tourist destination Mount Bromo has not become an attractive tourist destination in terms of connectivity is different from the city of Denpasar Bali, Batu City, and several other cities with the same tourist opportunities.

\section{Trickle-down Effect in Tourism Development}

The economy is sluggish amid US and China trade wars. That it needs a strategy to keep the economy running attractively for investors. Foreign exchange diversification become a considerable alternative [36]. One of the development strategies that can sustain the economy is the tourism sector. Deputy Director 
of Bank Indonesia has compiled studies in several countries and concluded that tourism can be a source of new growth which is relatively more resilient to global economic shocks and uncertainties [37].

The relevance of business tourism is also due to the current trend of millennials spending which places expenditure on traveling as a priority. It also amplified by the increasingly advanced digital technology that enables traveling easier than before. Though we are recently entering the new industrial revolution era, local authenticity such as natural beauty, unique culture, and friendliness of the population cannot be produced by technological factors.

This sector can be endowment resource of inclusive economic growth to reduce poverty and reduce unemployment for its engagement to businesses growth/local-based industries, such as the handicraft industry, culinary, vehicle rental, and hospitality sectors. Moreover, the importance of developing tourism is due to its reasonably ready to sell that it provides quick yielding.

However, even though tourism potential is very large, space for performance improvement and aggregate competitiveness are still extensive. Based on the Travel and Tourism Competitiveness Index (2017) by the World Economic Forum (WEF), Indonesia places an impressive increase in competitiveness by $42 \mathrm{nd}$ rank, from the previous 50th rank. However, when compared to other emerging economies, such as Malaysia (ranked 26th), Thailand [36], India [38], and China [15], we are still relatively lagging [39].

Accordingly, data from the World Travel and Tourism Council (WTTC) show that Indonesia's total tourism contribution has only reached 5.8 percent of gross domestic product (GDP) in 2017, while Thailand is $\mathbf{2 1 . 2}$ percent and Malaysia is 13.4 percent. The supply of foreign exchange recorded for Indonesia reached 14.4 billion US dollars, which still behind Thailand 59.6 billion US dollars and Malaysia 18.5 billion US dollars [40].

It has been the spirit of the government, business tourism as one of the strategic plans to advance the tourism industry in 2020-2024. The implementation was planned to target 10 national priority destinations that have been established as New Bali. In the list, the BromoTengger-Semeru tourist area is a strategic target for its development.

Business tourism was chosen because the tourist expenditure of this category is three times from ordinary tourists. Business tourism can also function as an alternative when it is quiet. The government targets foreign tourists coming to Indonesia as many as 17 million in 2018 and 20 million in 2019. The foreign exchange target is 17 billion US dollars in 2018 and 20 billion US dollars in 2019 [16].

Head of the Yogyakarta Center for Economic and Public Policy Studies, Gadjah Mada University, stated that foreign exchange proceeds from exports. However, not all tourism foreign exchange can become foreign exchange reserves. From around 1,100 US dollars per tourist visit, it estimated that only 700 US dollars converted into rupiah. This happens because there are still many foreign hotels and travel services using overseas payment services. Regarding foreign exchange tourism, most of the foreign hotels already owned by Indonesian. However, there are still payment systems that use foreign operator services with an average cost of around 7 percent per transaction [41]. Meanwhile, village tourism can develop optimally if infrastructure developed. In addition to that, the village needs to be encouraged to create entrepreneurs who can package the tourism potential of the village.

In line with the national government, local governments are also aggressively developing community-based tourism also known as ecotourism. This form of tourism aims to pioneer and sustain the village economy. It is believed that this form of business tourism would escalate people's income. Ecotourism is also proven to reduce the number of unemployment and reduce urbanization $[37,42]$.

The trickle-down effect occurs in many tourist destinations in the form of ecotourism in the Special Region of Yogyakarta. In the Special Region of Yogyakarta, villages such as Pentingsari Hamlet, Umbulharjo Village, Cangkringan SubDistrict, Sleman Regency, and Bejiharjo Village, Karangmojo District, Gunungkidul Regency become desired tourist destinations [38].

Of that income, $90 \%$ of which is enjoyed by the local community, while the remaining $10 \%$ is to improve infrastructure, conservation, and tourism development. Communities who used to be working in agricultural sector, now receive additional income from the tourism sector. Manager Ecotourism in Pentingsari Village admits residents would receive additional income of IDR 1-2 million per month, including in-house services, village specialties, and tour guides [38].

Village income previously averages IDR 5 million per month, now rises to IDR 200 million 
per month. The youth who migrated also began to return to the village because the wages of working in the village had exceeded the minimum wage of the DI Yogyakarta Province which this year was IDR 1.45 million per month. This condition is captured by Noor et al [43] which confirms the effect of ecotourism that's being amplified by social media engagement towards the local economy.

Even so, the impact of the trickle-down effect is unique. It doesn't guarantee that it would generate the same success on all tourist destinations. It caused by many factors such as synergy of institutions, political will, foreign payment systems, infrastructure, and sustainable tourism management.

First, the weakness of political will was voiced by Former Minister of Community Issues of President Abdurrahman Wahid Administration who wrote an opinion column in Kompas Cetak on March 13, 2010. According to him, political independence must include the determination of Indonesia's national tourism strategy. For example, by reviving tourism destinations that have been unnoticed, but only need a small touch to make them active again and become the main destination of tourists while reducing the pressure of excessive tourist burden that destroys Bali culture and nature.

Improving Indonesia's tourism must be done as quickly as possible, and the main requirement is to change the fundamental way of thinking of policy makers. The President must declare that tourism is a national priority and central or regional authorities, both government and private, are obliged to cooperate in this business. His recommendation includes building integrative infrastructure. With infrastructure investment, four places that are currently less well known can become potential tourist centers. It needs to be done to maintain the long-term continuation of the Indonesian tourism industry. As it reflected on research findings, Bromo Mountain and its tourism area still lack integrative infrastructure. Adequate improvements need to be built by the municipal government.

Second, infrastructure problems. Chairperson of the Institute for Research and Community Service at Atma Jaya University Jakarta writes predicaments faced by the tourism sector and the creative economy are typical of real economic problems in Indonesia. The competitiveness of the Indonesian economy in many cases held hostage to the poor availability of infrastructure and logistics systems. Not to mention the matter of investment climate and bureaucracy that are not encouraging. Thus, market and private investors are hesitating to build ports, roads, airports, expensive and unprofitable electricity transmissions. If the government wants to be present in the economy, these parts become homework that must be done immediately [41].

Former Minister of Tourism and Creative Economy writes how important it is to pay attention to facilities to realize the potential of tourism's contribution to foreign exchange. One of the recommendations proposed is the enactment of a visa-free policy and facilities for entering and leaving Indonesia so that tourists can visit comfortably with secure funds. She also adds that the friendly and efficient airport lattice is the speed of goods collection, access and smooth transportation to and from the airport, cleanliness and comfort, as well as tourism information services regarding the city/country concerned.

Besides, it is also important to design readiness of human resources. Preparation is in terms of services and human resources to infrastructure. For example, if you want to welcome many tourists from China, you must be prepared with tour guides and human resources in various elements of tourism services that can speak Mandarin. The adequate infrastructure is related to airports or ports, transportation connectivity, including direct flights, infrastructure, and tourism facilities. Finally, she suggests that there are plans to prepare tourist destinations and various tourism products. This variety of products can be local because it has added value that cannot be replicated by technology. Variety of product is also a channel for quality home industry products and high ethnic values added. Thus, tourists will stay longer and expend more foreign exchange.

The basic paradigm of tourism says more tourists who come to appreciate the distinctiveness of a tourist destination, more local people who will feel proud of their cultural and natural heritage so that they are more motivated to preserve it. It will then bring more tourists into harmony. All this will result in a mutually upward spiral of support between the local community and tourists who come together to strengthen the local heritage. This paradigm must be understood well by municipal governments.

Third, the synergy between institutions and local governments. Taking into account the 
results of the WEF's Travel and Tourism Competitiveness Index, three main factors that become records for tourism in the country, especially for the lowest competitiveness index, namely the availability of information and communication technology, tourism service infrastructure, and health and hygiene issues.

Indeed, the current government regime through relevant ministries has been enthusiastically active and highly committed to advancing the tourism industry over the past few years as outlined in the National Tourism Development Master Plan (2010-2025). Tourism development strategies designed include zoning (strategic areas), development of tourist destinations (creating $10 \mathrm{New}$ Bali, ranging from Toba in North Sumatra to Morotai in North Maluku), accessibility (facilities, infrastructure, and transportation), and community empowerment (tourism awareness). Then, promotion strategies (branding, advertising, and selling), including the implementation of international events; Meetings, Incentives, Conferences, Exhibitions (MICE); and halal tourism.

However, strategies and policy measures that have been intensively and extensively compiled by the central government, and the key to success is strongly influenced or dependent on the conditions/characteristics and responses of each region (province, city, and district).

\section{Trickle-Down Economics in Ngadisari Village}

There is central problem occurs in Mount Bromo Tourist Area near Ngadisari Village. Business tourism as a response to the development of Mount Bromo tourism was not mainly enjoyed by residents of Ngadisari Village but also from various regions outside Sukapura District. According to trickle-down economics approach, the advances promoted by private sectors will trickle instantly downward, creating jobs and economic opportunities; which in turn will foster conditions for a uniform distribution of economic growth outcomes. However, this condition is found inapplicable in Mount Bromo Tourist Area.

The theory implies that economic growth followed by the vertical flow from the rich to the self-impoverished population. As interviews have been conducted, we found that those who utilize the employment opportunities in Ngadisari Village are not natives of Ngadisari Village but from the regions other outside Sukapura District. Meanwhile, local people prefer to open their own business and do not work on the hotel owned by investors. From the problem then the authors conclude that trickle-down economics not running maximum in Ngadisari Village.

Trickle-down economics does not run optimally due to a number of latent problems such as lack of infrastructure, institutions synergy, and unintegrative support payment. It doesn't mean that no one takes advantage of economic blessing from the existence of Mount Bromo Tourist Area.

Mount Bromo located in Ngadisari region is a blessing of its local economy. Local people have chances to run various business opportunities that can be offered to the tourists not only domestic but also the scope overseas ranging from selling knick-knacks, specialty foods, horses, jeeps, T-shirts, hotels, inns, and others. It makes the people's economy gradually increased, plus the community continues to do economic activities or the main livelihood of cultivation. Agriculture is the main livelihood of rural communities Ngadisari, given Ngadisari Village is suitable for agricultural activities, so many local people still farmed despite seeking additional economy by utilizing Mount Bromo Sightseeing [22].

From the trickle-down economics in Ngadisari Village explanation above, it is necessary for public to be open minded with towards all developments which will aim to improve economy of society. The society should utilize investor which open business opportunity that exploited its existence to become job opportunity for local community of Ngadisari Village. Therefore, equality of development can be realized in the poor society. This attitude can be realized by allowing the presence of local governments to make progress in the field of road connectivity and other public infrastructure, as well as the presence of law enforcement to ensure the security to the tourist destinations.

\section{CONCLUSION}

The existence of the development of the tourist destination of Mount Bromo that makes an economic change is an unavoidable thing. The result from the investment of private party and effort from society to improve the economy of its family, makes the society to find a gap that can increase its daily income as well as society in Ngadisari village though not maximal. Based on the findings, trickle-down economics in Ngadisari is a business opportunity for the tourism destination of Mount Bromo, which is utilized by some people of Ngadisari. Although only a small 
portion utilizes investors from outside Ngadisari, it has not contributed enough to inclusive economic growth in Ngadisari. Thus, the trickledown economics approach in Ngadisari was not maximal.

\section{REFERENCES}

[1] Ackerman, F. 1982. Reaganomics: rhetoric vs. reality. South End Press. Boston.

[2] Ahmad, S.K. 2004. Teori pembangunan ekonomi. Utusan Publication and Distributors; (Siri pengajian dan pendidikan Utusan). Available at: https://books.google.co.id/ books?id=9vNk5z10TgC.

[3] Arestis, P., M. Baddeley, and J. S. L. McCombie. 2007. Economic growth: new directions in theory and policy. Edward Elgar Publishing. Cheltenham.

[4] Bartlett, B. 2009. The new American economy: the failure of Reaganomics and a new way forward. St. Martin's Press. New York.

[5] Buchanan, J. M. 1989. Reaganomics and after. Institute of Economic Affairs. London.

[6] Collis, J. and R. Hussey. 2003. Business research. Palgrave Macmillan. New York.

[7] Lehmans, D.J. 2015. Understanding trickledown economics. CreateSpace Independent Publishing Platform. California.

[8] Niskanen, W. A. 1988. Reaganomics: an insider's account of the policies and the people. Oxford University Press. Oxford.

[9] Niskanen, W. A. 1992. Reaganomics. In: Henderson, D. R. (Ed). Concise encyclopedia of economics, $1^{\text {st }}$ Ed. Library of Economics and Liberty.

[10] Permadi, D. 2012. Runtuhnya neoliberalisme global : analisis ekonomi politik tentang kemunduran neo-liberalisme dan peluang kebangkitan neo-keynesianisme. Department of International Relation, Gadjah Mada University. 2011 ed. Institute of International Studies; Available at: http://hi.fisipol.ugm.ac.id/book/runtuh nya-neo-liberalisme-global-analisisekonomi-politik-tentang-kemunduran-neoliberalisme-dan-peluang-kebangkitan-neokeynesianisme/.

[11] Persky, J., D. Felzenshțain, and V. Carlson. 2004. Does "trickle down" work?: economic development strategies and job chains in local labor markets. W.E. Upjohn Institute. Michigan.
[12] Pultar, G. 2014. Imagined identities: identity formation in the age of globalization. Syracuse University Press. New York.

[13] Ritzer, G. and J. Stepnisky. 2017. Modern sociological theory. SAGE Publications.

[14] Schaffner, J. 2014. Development economics: theory, empirical research, and policy analysis. NJ: Wiley. Hoboken.

[15] Schumpeter, J. A. 1983. The theory of economic development: an inquiry into profits, capital, credit, interest, and the business cycle. NJ: Transaction Books, Social Science Classics Series. New Brunswick.

[16] Seip, J., and D. W. 2016. Harper the trickledown delusion: how republican upward redistribution of economic and political power undermines our economy, democracy, institutions and health-and a liberal response. UPA.

[17] Selowsky, M. 1979. Balancing trickle down and basic needs strategies: income distribution issues in large middle-income countries with special reference to Latin America. World Bank.

[18] Sharpley, R. and D. J. 2002. Telfer tourism and development: concepts and issues. Channel View Publications. Brsitol.

[19] Sowell, T. 2013. Trickle down theory and tax cuts for the rich. Hoover Press. Stanford.

[20] Staff, B. S. G. 2011. Reaganomics in plain and simple english. BookCaps Study Guide.

[21] Todaro, M. P. and S. C. Smith. 2006. Economic development. Erlangga. Jakarta.

[22] Hakim, L. and M. Soemarno. 2017. Biodiversity conservation, community development and geotourism development in bromo-tengger-semeru-arjuno biosphere reserve. Geojournal of Tourism and Geosites 20(2), 220-230.

[23] Yoety, O. A. 1999. Industri pariwisata dan peluang kesempatan kerja. Pertja Pubisher. Jakarta.

[24] Yoety, O. A. 2008. Ekonomi pariwisata: introduksi, informasi, dan aplikasi. Kompas Book Publisher. Jakarta.

[25] Morais, D. 2013. Malaysia: truly asia. Double consciousness in Malaysia's tourism advertising, or the double jeopardy of being Malaysian. 92-110.

[26] Cutler, D. and Katz L. 1991. Macroeconomic performance and the disadvantaged. Brookings Papers on Economic Activity 2, 174.

[27] Czaika, M. and H. de Haas. 2014. The globalization of migration: has the world 
become more migratory?. International Migration Review 48(2), 283-323.

[28] Nirwandar, S. 2004. Pembangunan sektor pariwisata di era otonomi daerah. Ministry of Tourism. Jakarta.

[29] Nizar, M. A. 2011. Pengaruh pariwisata terhadap pertumbuhan ekonomi di Indonesia. Jurnal Kepariwisataan Indonesia 6(2), 195-211.

[30] Okun, A. 1973. Upward mobility in a highpressure economy. Brookings Papers on Economic Activity 1(1), 207-252.

[31] Taufiqurrohman, M. 2014. Strategi pengembangan pariwisata serta kontribusinya pada penerimaan retribusi Kota Pekalongan. Economics Development Analysis Journal 3(1), 81-91.

[32] Zaenuri, M. 2012. Perencanaan strategis kepariwisataan daerah konsep dan aplikasi. E-Gov Publishing. Yogjakarta.

[33] Suwardiman. Memetakan daya saing industri pariwisata daerah. 2016. Available at: https://kompas.id/baca/riset/2016/12/ 01/memetakan-daya-saing-industripariwisata-daerah/.

[34] Wartakota. 2017. Wah, Seoul sediakan informasi wisata dalam Bahasa Indonesia. Wartakota Available at: http://wartakota. tribunnews.com/2017/05/04/wah-seolsediakan-informasi-wisata-dalam-bahasaindonesia.

[35] Hakim, L., M. Soemarno, and S. K. Hong. 2012. Challenges for conserving biodiversity and developing sustainable island tourism in North Sulawesi Province, Indonesia. Journal of Ecology and Environment 35(2), 61-71.

[36] Yee, C. F. 2017. Singapore remains a central hub for company formations despite drop in overall Q4 figures. AntaraNEWS. Available at: http://www.antaranews.com/en/news/ 103038/singapore-remains-a-central-hubfor-company-formations-despite-drop-inoverall-q4-figures.

[37] Aditya H., T. 2016. Diplomasi pariwisata Asean di pasar global. Master Thesis. Gadjah Mada University. Available at: http://etd.repository.ugm.ac.id/index.php? mod=penelitian_detail\&sub=PenelitianDeta il\&act=view\&typ=html\&buku_id=106472\&o byek_id=4.

[38] Antara News. 2017. BI: sektor pariwisata berpotensi dorong pertumbuhan ekonomi Available at: https://www.antaranews.com/ berita/658816/bi-sektor-pariwisataberpotensi-dorong-pertumbuhan-ekonomi.
[39] Harimawan, R. G. and W. Hidayati. 2012. Analisis keunggulan komparatif sektor pariwisata Indonesia di kawasan Asia Tenggara (ASEAN). Master Thesis. Gadjah Mada University. Available at: http://etd.repository.ugm.ac.id/index.php? mod=penelitian_detail\&sub=PenelitianDeta il\&act=view\&typ=html\&buku_id=55460\&ob yek_id=4.

[40] Rokhmah I., A. 2016. Faktor-faktor yang mempengaruhi penerimaan pariwisata internasional di Asean-5, 1999-2014. Master Thesis. Gadjah Mada University. Available at: http://etd.repository.ugm.ac.id/index. php?mod=penelitian_detail\&sub=Penelitian Detail\&act=view\&typ=html\&buku_id=9583 8\&obyek_id=4.

[41] Rahmayanti E. 2015. Daya saing pariwisata menuju komunitas ASEAN 2015. Bachelor Thesis. Gadjah Mada University. Available at: http://etd.repository.ugm.ac.id/index. php?mod=penelitian_detail\&sub=Penelitian Detail\&act=view\&typ=html\&buku_id=9009 3\&obyek_id=4.

[42] Utama, M. S. 2006. Pengaruh perkembangan pariwisata terhadapkinerja perekonomian dan perubahan struktur ekonomi serta kesejahteraan masyarakat di Provinsi Bali. PhD Thesis. Airlangga University. Surabaya.

[43] Noor, A. R. 2017. Orang Indonesia doyan jalan-jalan, setahun habiskan Rp 33 Miliar Available at: https://inet.detik.com/ business/d-3778751/orang-indonesiadoyan-jalan-jalan-setahun-habiskan-rp-33miliar. 